\title{
A Relação Teoria-Prática Docente no Ensino de Ciências: uma Análise Materialista Histórico-Dialética à Luz da Práxis Autêntica de Freire
}

The Relationship Between Theory and Practice in Science Teacher Education: A Historical-Dialectical Materialist Analysis in the Light of Freire's Authentic Praxis

\author{
(D) Cristiane Aparecida Madureira, Juliana Rezende Torres
}

\begin{abstract}
Palavras-chave Resumo Entender a práxis pedagógica permeia compreender a Marxismo; dialética implícita ao ato educativo. Buscando entendimento pela ótica Paulo Freire; das dimensões praxiológicas em que as práticas pedagógicas se situam, Trabalho Docente. o trabalho docente fez-se objeto de estudo, visando dimensionar limites e possibilidades do ato de Ensino de Ciências de um grupo docente da rede pública estadual paulista, na relação teoria-prática docente, à luz da práxis autêntica freireana. Empregou-se observação participante e entrevistas estruturadas, tomando o conceito de práxis em Marx como categoria analítica a priori, desdobrando-se em dimensões praxiológicas em Lefebvre e Vázquez até a práxis autêntica de Freire. Tais dimensões da práxis foram balizadas a partir de estruturantes (sujeitos, contextos e processos) em suas respectivas variações, bem como nos níveis de consciência de Freire acerca da teoria-prática docente. Resultados apontam que a dimensão da práxis pedagógica que o docente se encontra depende do movimento dialético dos estruturantes da práxis atrelado aos níveis de consciência acerca do trabalho docente, o que pode estar mais próximo da dimensão da inversão da práxis, da dimensão transicional ou da dimensão da práxis autêntica. Esta pesquisa propiciou a elaboração de um construto teórico em torno dos estruturantes da práxis pedagógica em suas respectivas variações, visando a explicitação da dimensão da práxis pedagógica dos docentes investigados frente às suas próprias posturas epistemológicas e pedagógicas.
\end{abstract}


Keywords Abstract Understanding pedagogical praxis comprises

Marxism; understanding the dialetics implicit to the educational act. In search of

Paulo Freire; comprehension through the standpoint of praxiological dimensions

Teaching Work. which host pedagogical practices, this study focused on the work of faculty members, aiming at defining limits and possibilities of science teaching of a group of teachers in public schools of the state of São Paulo, Brazil, in the teacher theory-practice relationship, in light of the authentic praxis of Freire. Participant observation and structured interviews were employed, borrowing the concept of praxis in Marx as an analytical category a priori, unfolding it into praxiological dimensions in Lefebvre and Vázquez until the authentic praxis of Freire. Such praxis dimensions were set based on structuring elements (subjects, contexts, and processes) in their respective variations, as well as in the awareness levels of Freire on teacher theory-practice. The results indicate that the dimension of pedagogical praxis in which teachers are located depends on the dialectic movement of the structuring elements of the praxis coupled with the awareness levels towards teaching, which may be closer to the dimension of inversion of the praxis, the transitional dimension, or the dimension of authentic praxis. This research enabled the creation of a theoretical construct around the structuring elements of pedagogical praxis in their respective variations aiming at revealing the dimension of the pedagogic praxis of the teachers investigated in face of their own epistemological and pedagogical postures.

\section{Introdução}

Para Freire (1996), a educação é um ato político. Essa compreensão nos remete ao cerne da ação educativa, o processo ensino-aprendizagem. Ensinar requer direcionamento, sentido e significado. Ao ensinar, o educador ${ }^{1}$ se apoia em determinadas posturas metodológicas e parâmetros metódicos, que se estruturam primordialmente a partir de sua visão de mundo. A concepção de ensino, de educação, de currículo, de escola e de sociedade de cada educador/a está implicada em sua concepção de Ciência, correlacionada às suas visões sobre ser sujeito no mundo e sobre atribuir sentidos e significados à essa forma de ser, estar e agir no mundo (Torres, 2000). Ensinar então, se torna ato de ação, reflexão e (re) ação, de constante retomada e reconstrução, pela interação com o meio e com o outro. Assim, o processo ensino-aprendizagem como ato político está atrelado à relação teoria-prática, ou seja, à dimensão de práxis da prática docente.

1 Para a escrita estamos considerando o gênero masculino em respeito às normas da língua portuguesa. 
A práxis, segundo Marx (2005), é uma característica humana. Como tal, a ação docente ou prática educativa em seu cotidiano é o que chamamos de práxis pedagógica. Ato contínuo dos educadores, à práxis estão relacionadas ações, reflexões, reações e intencionalidades docentes, de modo a se depreender as várias subjetividades subjacentes e, consequentemente, implicações daí decorrentes na conjuntura histórico-sociocultural (Franco \& Gilberto, 2010; Caldeira \& Zaidan, n.d). Ensinar Ciências é uma maneira de compreender o mundo, e compreender o mundo vai além de se contemplar fatos e acontecimentos históricos e refletir sobre eles. É preciso a ação sobre as reflexões, tanto no ambiente em que se encontra, como na própria construção pedagógica. Ao professor de Ciências não basta ser reflexivo, é preciso ser transformador de sua prática pedagógica. Essa reflexão crítica sobre a prática, com vistas à transformação, é chamada por Freire (1987) de práxis.

No campo pedagógico, Freire (1987) nos diz que a prática pedagógica libertadora voltada à humanização dos sujeitos, se faz pela práxis autêntica. Freire compreende a práxis a partir da filosofia marxista, o materialismo histórico-dialético (MHD), em que a práxis é concebida a partir do conceito de trabalho, ou seja, como ato de transformação da realidade concreta mediante ação humana na natureza, a partir de suas necessidades materiais e/ou socioculturais. Assim, nessa perspectiva, educar, ensinar, aprender se fazem sinônimos de compreensão e transformação do mundo. Educar vai além do ato instrumentalizador e mecânico de transmitir conhecimentos. Portanto, para Freire (1987), educar é ação, reflexão e (re) ação, de modo que educar para a transformação da realidade concreta implica em práxis pedagógica autêntica, enquanto educar para a adaptação à realidade implica em inversão da práxis.

A totalidade do trabalho docente (relação teoria-prática), nos remete à ideia que a práxis pedagógica em alguma dimensão se faz presente, independentemente do nível de consciência que o docente possa ter de sua própria prática docente, se tradicional, transicional ou progressista - o que se torna fundamental para dimensionarmos sua práxis pedagógica. A prática pedagógica do ensino das Ciências da Natureza se faz por percursos praxiológicos através de um conjunto interativo entre educadores-educandos.

No âmbito de estudos praxiológicos freireanos na área de pesquisa em educação em Ciências, destacamos Stuani (2016) e Lima (2019) que tecem considerações acerca da efetivação da práxis criadora de Vázquez (1977) articulada à práxis freireana. Stuani (2016) em sua tese de doutorado argumenta e defende a dinâmica da Abordagem Temática Freireana (Delizoicov et al., 2002) como um processo de formação permanente dos professores, cujo argumento central reside no fato desta dinâmica estar fundamentada na Investigação Temática de Freire (1987), que, por sua vez, se configura como processo de elaboração do conhecimento como racionalidade dialógica de uma práxis criadora. Lima (2019), em sua dissertação de mestrado, se fundamenta na Investigação Temática de Freire (1987) para a construção de um Projeto Político-Pedagógico (PPP) humanizador, configurado como práxis criadora e reflexiva. Para tal, Lima (2019) caminha metodologicamente em situações contextuais ambientadas no convívio social 
e cultural da comunidade, onde a protagonização dos sujeitos envolvidos é mediada por um processo de humanização e diálogo. Desta forma, ambos os trabalhos trazem elementos de uma práxis criadora em Vázquez (1977) articulada à concepção de práxis em Freire (práxis autêntica), via Investigação Temática, que explicita uma concepção educacional libertadora e uma concepção de currículo crítico-libertador pela via dos temas geradores que sintetizam contradições sociais vividas localmente e inseridas na macroestrutura sociopolítica-cultural. Ambas as pesquisas trazem avanços para a área de pesquisa em Educação em Ciências no sentido de explicitar e situar a Investigação Temática Freireana como práxis criadora, seja no âmbito da formação permanente de professores, seja na elaboração de um PPP de cunho humanizador. Todavia, a área de pesquisa em educação em Ciências carece do avanço de estudos alinhados a esse referencial marxiano de práxis criadora em Vázquez na sua relação com a práxis autêntica em Freire, no sentido de prosseguir na construção teórica que permita identificar a dimensão praxiológica em que os docentes de ensino de Ciências da Natureza se situam, no contexto da relação teoria-prática do seu trabalho docente.

Com efeito, educar cientificamente é um ato político, pois, carrega um conjunto de intencionalidades, de pensares, de fazeres, de compreensões sobre Ciência e seu ensino. Propositalmente ou não, cada educador leva para a sala de aula suas intencionalidades, visões de mundo, metodologias e métodos. Em seu ato de ensino o professor segue um caminho metodológico e metódico, que pode estar alinhado ao pensamento tradicional de ensino de Ciências, onde impera a subordinação dos alunos - e também a sua - às regras, conceitos, fórmulas e comportamentos normativos. Outras vezes, a linha seguida pelos educadores se pauta em uma pedagogia emancipatória, progressista, cientificamente crítica, em busca de um percurso educacional libertador, tanto dos educandos, como de si próprios. Ambos os caminhos se aproximam, por perspectivas diferentes, de dimensões distintas do conceito ontológico de práxis. Para este trabalho, tais dimensões da práxis estão aglutinadas em torno da práxis pedagógica autêntica de Paulo Freire e do seu inverso, a inversão da práxis, ou seja, adotamos autores no âmbito do MHD (como Lefebvre e Vázquez) que consideram que, para alcançar a práxis transformadora de Marx (em Freire, práxis autêntica), se faz necessária a movimentação dialética de um nível de consciência em torno da práxis para outro nível em transitividade, até se chegar à práxis transformadora/ criadora/autêntica.

Com o objetivo de explicitar as dimensões da práxis pedagógica de um grupo de docentes de Ciências da Natureza da rede pública de ensino estadual paulista, à luz da práxis pedagógica autêntica de Paulo Freire, emergiram as seguintes perguntas que direcionaram esta pesquisa: Quais dimensões da práxis pedagógica orientam um grupo de docentes de Ciências da Natureza da rede pública de ensino estadual paulista, frente à relação teoria-prática pedagógica? Em que medida tais dimensões da práxis pedagógica desses docentes se aproximam ou se distanciam da práxis autêntica de Freire? 


\section{Os fundamentos marxistas da práxis e seus desdobramentos dimensionais}

Práxis é ação, reflexão e (re) ação. Sua compreensão como ato orientador da ação ontológica concreta se dá a partir de Marx, fundamentado pelo MHD. Para Marx (2005), as bases do MHD perpassam por ações humanas ligadas à práxis, e são de fato praxiológicas quando buscam um viés transformador, levando à um caminhar social emancipador. A obra marxista, apesar de pautada filosoficamente na práxis, não dimensiona a estrutura praxiológica que a embasa. Assim, as dimensões da práxis em Marx acabam por ser mais bem apuradas por Lefebvre (1975), que ao refletir o conceito de práxis em Marx, a ressignifica em sua complexidade filosófica, conduzindo-a para um movimento vivo e ativo na direção da práxis transformadora. O filósofo, considerando em sua obra as diversas reflexões de outros marxistas, como Gramsci e Lukács ${ }^{3}$, parte do princípio de que há várias divergências entre os conceitos encontrados, sendo necessário um explicitar mais efetivo do conceito de práxis marxista.

Ao aprofundar o conceito de práxis proposto pelo MHD, Lefebvre (1975) vai além e traz à tona a emersão social da práxis. Para Marx (2005), a dialogicidade da práxis gira em torno da transformação, e qualquer intencionalidade fora essa, não a legitimaria como tal. Porém, Lefebvre (1975) e Vázquez (1977) propõem direcionamentos para o alcance da práxis transformadora em Marx. Com efeito, como movimento vivo e dialético, a práxis não age exclusivamente como causa transformadora, mas, a depender do sentido de seu movimento, também como mantenedora da inércia das práticas humanas. Assim, Lefebvre (1975) propõe que há dimensões praxiológicas distintas para a atividade humana: práxis reprodutora (que mantém a reflexão e a ação da práxis em inércia); práxis imitativa (há movimento reflexivo, mas sem ação transformadora) e, práxis transformadora (reflexão e ação avançam juntas para a transformação). Posteriormente, Vázquez (1977) propõe tipificações da práxis, similares e respectivas às dimensões atribuídas por Lefebvre: práxis reiterativa, mimética e criadora. Desta forma, há correlações entre as três dimensões da práxis propostas por Lefebvre (1975) e as três dimensões da práxis propostas por Vázquez (1977). Ou seja, há correlação entre a práxis reprodutora e a reiterativa, assim como há correlações entre a práxis imitativa e a mimética, e ainda há correlação entre a práxis transformadora e a criadora.

No campo educacional, Freire (1987), ao propor o direcionamento da Educação Libertadora, propõe uma didática para além dos campos reflexivos e empíricos. Para ele, a pedagogia só se faz verdadeira e revolucionária, quando a prática pedagógica se faz pela práxis autêntica. Freire reconhece a práxis autêntica como a única capaz da transformação, a que leva os homens e mulheres à construção do ser mais. Este posicionamento freireano em relação à práxis, explicitado ao longo de sua obra, o coloca alinhado ao referencial de práxis marxiana, que considera a práxis transformadora como

2 Antonio Gramsci (1891-1937), italiano, foi um filósofo marxista, jornalista, crítico literário e político.

3 Georg Lukács (1885-1971), húngaro, foi um filósofo e historiador marxista. 
a única possível para a transformação social ${ }^{4}$. Em contrapartida, as demais práticas humanas que se constroem no caminho rumo à práxis autêntica, são denominadas por Freire como inversão da práxis. Todavia, para outros marxistas como Lefebvre e Vázquez o caminho para a práxis transformadora/criadora também é considerado em suas diferentes dimensões. Dimensionar esse caminho praxiológico do trabalho docente até a práxis transformadora/autêntica via elaboração de um construto teórico é exatamente o foco da presente pesquisa. Tais dimensões praxiológicas podem ser visualizadas na figura 1, com a ressalva de que Freire se volta para a dimensão praxiológica pedagógica.

Figura 1. As dimensões da práxis à luz dos referenciais marxistas desta pesquisa

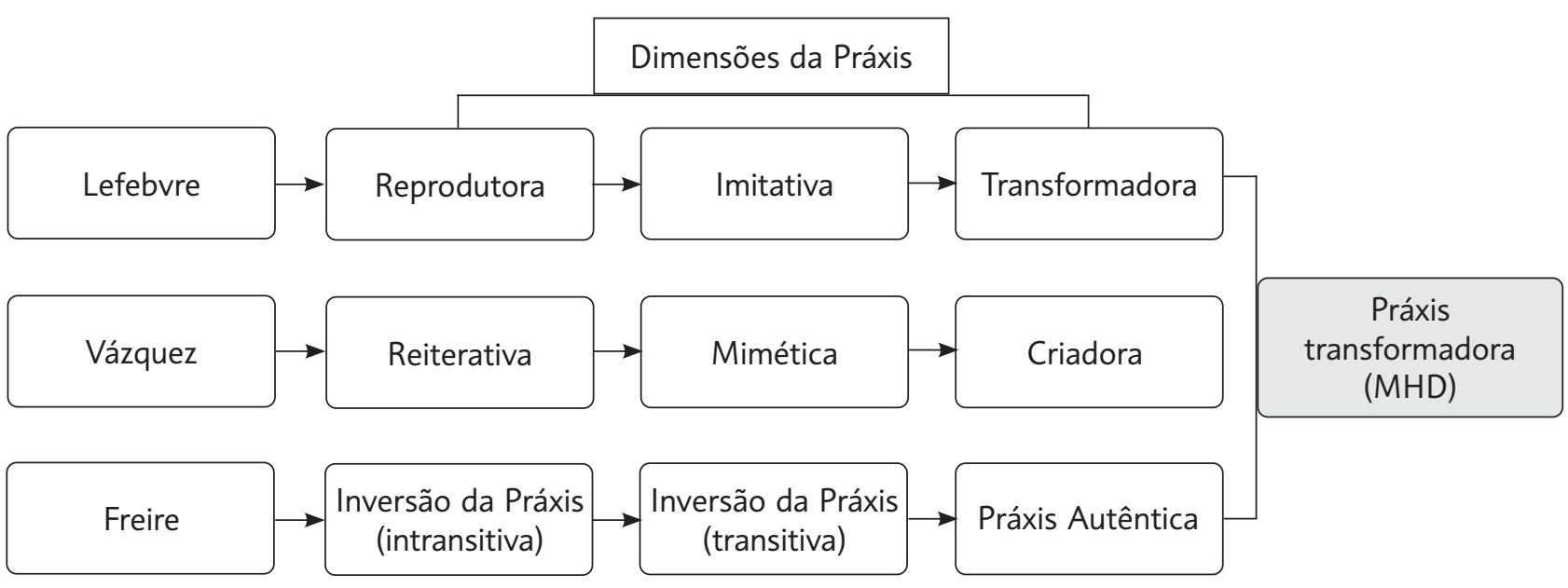

Fonte: Elaboração própria.

Com efeito, as relações estabelecidas entre as dimensões da práxis marxiana se encontram sistematizadas na figura 1 , de maneira que as setas indicam que as dimensões da práxis estão atreladas a um movimento contínuo, condicionado dialeticamente pela consciência em torno do trabalho docente, tendo como horizonte a práxis transformadora/criadora/autêntica, no contexto do MHD.

As considerações de Lefebvre (1975), a partir da complexidade e amplitude da dimensão da práxis considerada por Marx, foram fundamentais para a acomodação dos referenciais deste trabalho. A partir delas, nos foi possível a construção de um conceito de práxis, que reflete a compreensão de seu sentido abstrato e material: "A práxis é ato humano inerente e ontológico. Envolve indissociavelmente ação, reflexão e (re) ação pelo retorno à ação. É produto histórico, mas é também processo ontológico ativo de criação humana. Emerge da necessidade humana, destruindo, criando e reconstruindo novas necessidades, à medida que supera as primárias. Está ligada intimamente ao trabalho, sendo esse a força motriz, contraditória e dialética que lhe envolve em todas as relações, inclusive as relações de dominação e apropriação da natureza, da sociedade e da cultura".

4 Entrevista dada por Freire em que relata suas aproximações ao referencial marxista. (https://www.youtube.com/ watch? $v=$ Uvdc2YlcZkE\&ab_channel=RafaelVieira) 
A práxis se faz complexa, móvel e variável, e, é condicionada pela consciência humana. Para observá-la em sua complexidade, é necessário captar suas dimensões, através dos estruturantes que a movem dialeticamente. Para essa pesquisa, se fez necessário definir quais seriam esses estruturantes e suas respectivas variações, para dimensionar a práxis pedagógica dos docentes. Para construirmos tais estruturantes da práxis, nos debruçamos na pesquisa de Silva (2004) que considera que a prática educativa está arraigada em um contexto que se manifesta nas dimensões da realidade, na articulação entre sujeitos e processos, e suas inter-relações socioculturais.

De tal modo, nesta pesquisa, assinalamos os seguintes estruturantes para o dimensionamento da práxis: a) Se "a práxis é ato humano inerente e ontológico, envolve indissociavelmente, ação, reflexão e retorno a ação" então ela está intimamente ligada ao seu primeiro elemento: o sujeito da ação; b) Se "é produto histórico, mas é também processo ativo da criação humana e emerge da necessidade humana, destruindo, criando e reconstruindo novas necessidades, à medida que supera as primárias", então se faz indissociável um segundo elemento inerente à construção histórica humana, o processo; c) Se "está ligada intimamente ao trabalho, sendo esse a força motriz, contraditória $e$ dialética que the envolve em todas as relações, inclusive as relações de dominação e apropriação da natureza, da sociedade, da cultura", é fundamental que se considere para a compreensão da práxis, um terceiro elemento, o contexto dessa atuação.

Portanto, uma vez considerada as correlações das dimensões da práxis marxiana entre Marx, Lefebvre, Vázquez e Freire, conforme expressas na figura 1, adotamos a priori os estruturantes sujeitos, contextos e processos, que possibilitaram dimensionar a práxis pedagógica dos docentes investigados. Imprescindível para a transição de uma dimensão praxiológica a outra é a atuação ativa da consciência. Na convergência da compreensão do conceito de práxis entre os marxistas, a consciência da práxis é o congruente entre Marx, Lefebvre, Vázquez e Freire:

Somente o homem pode distanciar-se do objeto para admirá-lo. Objetivando ou admirando - admirar se toma aqui no sentido filosófico - os homens são capazes de agir conscientemente sobre a realidade objetivada. É precisamente isto, a "práxis humana", a unidade indissolúvel entre minha ação e minha reflexão sobre o mundo. (Freire, 1979, p. 15).

Não é a intencionalidade dessa pesquisa adentrar profundamente nos níveis de consciência de Freire (1987). Mas, como a consciência se faz em níveis, e estes condicionam e direcionam o movimento dialético das dimensões da práxis, é imprescindível que a discussão em torno dos níveis de consciência seja ponderada, visto ser premissa freireana para o movimento praxiológico.

Freire (1979) destaca que o homem é um corpo consciente. Para tanto, a consciência humana do mundo, perpassa o mundo da consciência. Não há mundo sem consciência, nem consciência sem mundo. Como agente ativador praxiológico, a consciência dita o ritmo no movimento dialético do pensar e do agir, do fazer e do refletir. Dessa maneira, o desenvolvimento da práxis, como característica ontológica 
humana, está indissoluvelmente ligado à consciência humana, como cita Oliveira \& Carvalho (2007):

Não se pode conceber a consciência espacialmente, como um receptáculo vazio presente no homem que deve ser preenchido. A consciência intencional provoca uma aproximação reflexiva à realidade. Não é a realidade que entra na consciência, mas a consciência reflexiva que tende à realidade, criando a possibilidade da práxis com a ação e a reflexão. É sempre uma consciência historicamente condicionada, sem ser uma mera reprodução da realidade. (Oliveira \& Carvalho, 2007, p. 221).

A consciência se faz intencional à realidade. Essa intencionalidade está ligada ao movimento da práxis, às suas dimensões e aos seus estruturantes. Se não é a realidade que entra na consciência, e sim a consciência que adentra à realidade, é imprescindível suas intencionalidades dirigidas a um contexto social, cultural, econômico e principalmente histórico. Para Freire (1979) são as situações em que os homens e mulheres se encontram que movem seus níveis de consciência: consciência de imersão (em que se encontram imersos na realidade, sem refleti-la ou modificá-la), consciência de emersão (onde há a reflexão do real) e consciência de inserção (o retorno dos homens e mulheres à realidade para transformá-la através de sua práxis autêntica).

A consciência humana não aceita passividade. Foi considerando as reflexões de Goldmann (1974) sobre a inquietude da consciência humana, que Freire (1979) compôs os níveis de consciência humana, propulsores da práxis: a consciência intransitiva, que está ligada ao estágio de imersão; a consciência transitiva ingênua, ligada ao estágio de emersão; e a consciência transitiva crítica, ligada ao estágio de inserção praxiológica. Em Freire (1987) pautado em Goldmann (1974), podemos associar tais níveis de consciência, respectivamente, à: consciência real efetiva, consciência máxima e consciência máxima possível. Com efeito, os dois primeiros níveis de consciência (real efetiva e máxima) de Freire (1987) podem ainda ser compreendidos como alinhados à inversão da práxis (em níveis distintos) e, o terceiro nível de consciência de Freire (máxima possível), como alinhado à práxis autêntica.

Desta forma, à luz dos referenciais marxistas desta pesquisa foram definidos os estruturantes da práxis que possibilitaram a investigação de maneira mais precisa da dimensão da práxis pedagógica em que cada docente se situa. Com efeito, as variações dos estruturantes da práxis pedagógica emergiram em conformidade com o gradiente dimensional praxiológico analisado relacionados aos níveis de consciência dos docentes em torno de seu trabalho docente (o que se encontra melhor explicitado no item percurso metodológico), cujas variações foram assim configuradas e suas correlações podem ser visualizadas na figura 2 :

- Sujeito: refere-se à educadores e educandos. Pode ser: coisificado (acríticos e neutros; professor e aluno são objetos na práxis educativa); coparticipante (professor e aluno são sujeitos no processo; pode haver neutralidade, mas em imitação à práxis autêntica) e, ativo (atuante, transformador, produtor no processo ensino-aprendizagem, professor e aluno são sujeitos no processo). 
- Processo: refere-se ao processo educativo de ensino-aprendizagem. Pode ser: linear (acrítico, mecânico, transmissor de conhecimento, neutro); espelhado (por seu caráter imitativo da práxis autêntica o espelhar-se pode ser problematizador no âmbito das interações socioculturais, conscientizador, participativo, transformador, político e histórico, mas, não inédito) e, humanizador (problematizador no âmbito das interações socioculturais, conscientizador, participativo, transformador político e histórico).

- Contexto: refere-se ao ambiente histórico, mediador do conhecimento. Pode ser: empírico (mediador epistemológico empírico, selecionado à priori); reflexivo (mediador epistemológico da prática docente, cuja reflexão, de forma isolada, não leva à ação praxiológica) e, praxiológico (mediador epistemológico da práxis pedagógica, emerge da contradição social, cuja reflexão culmina em ação praxiológica).

Figura 2. As dimensões da práxis pedagógica relacionadas aos estruturantes da práxis mediados pelos níveis de consciência em Freire

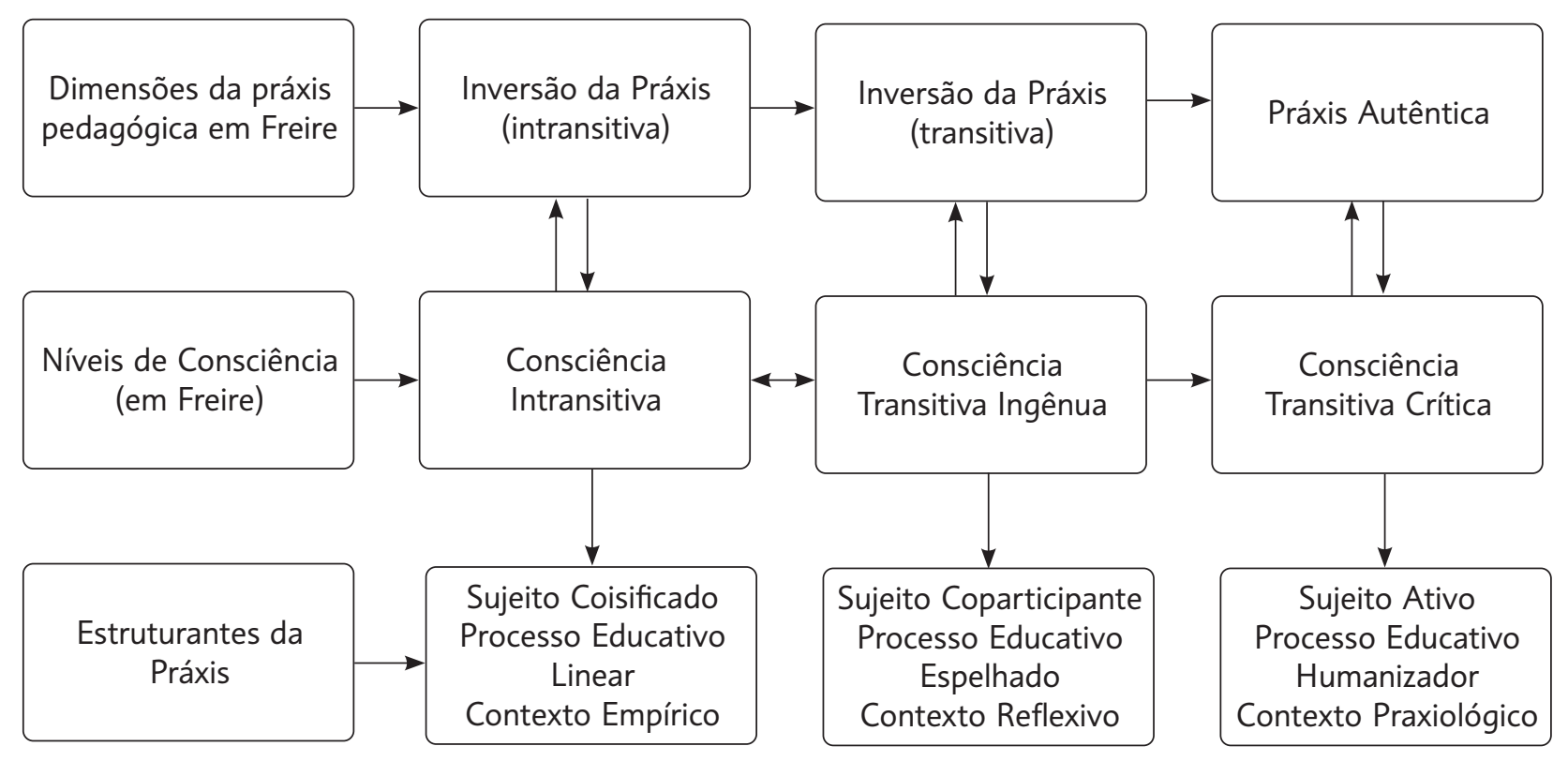

Fonte: Elaboração própria.

Portanto, a inquietude da consciência humana se dá pela própria dinâmica do movimento dialético em torno das práticas sociais, de forma que, em campo abstrato, a reflexão se faz sobre o campo concreto dessas práticas, trazendo à luz distintas possibilidades dimensionais da práxis. Um exemplo de prática social é a prática pedagógica. Assim, em contextos pedagógicos, ponderamos que o movimento dialético implica na indissociabilidade entre a tríade prática docente, níveis de consciência e dimensões da práxis pedagógica, atuando diretamente no trabalho docente, de modo a aproximá-lo da práxis pedagógica autêntica ou mantê-lo em estado de inércia, na dimensão da inversão da práxis. A dinâmica do movimento dialético em torno dessas 
relações pode ser visualizada na Figura 3:

Figura 3. Indissociabilidade do movimento dialético na tríade prática docente, níveis de consciência e dimensões da práxis pedagógica

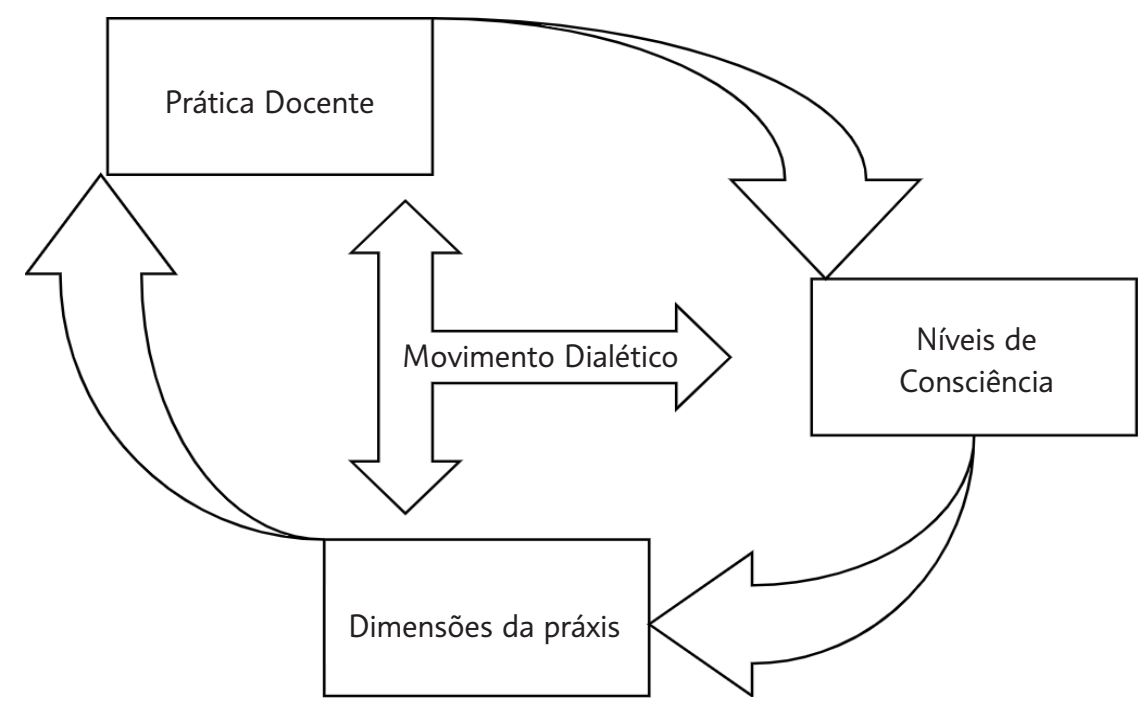

Fonte: Elaboração própria.

Diante das relações estabelecidas nessa figura cabe ressaltar que o movimento dialético é o propulsor da tríade em sua totalidade, sendo necessário o movimento conjunto da tríade para que se alcance a dimensão da práxis pedagógica autêntica. A dimensão praxiológica não se movimenta de maneira voluntária, independente e solitariamente na dinâmica da tríade. A consciência, quando em inércia, impede a movimentação dos outros elementos da tríade.

Ao nível das consciências humanas, sobre a consciência intransitiva, diz Freire:

[...] o conceito de 'intransitividade' não corresponde a um fechamento do homem dentro dele mesmo, esmagado, se assim o fosse, por um tempo e um espaço todo poderosos. O homem, qualquer que seja o seu estado, é um ser aberto. $\mathrm{O}$ que pretendemos significar com a consciência 'intransitiva' é a limitação de sua esfera de apreensão. É a sua impermeabilidade a desafios situados fora da órbita vegetativa. Neste sentido e só neste sentido, é que a intransitividade representa um quase descompromisso do homem com a existência. (Freire, 1987, p. 60).

As aproximações possíveis do nível de consciência intransitiva do docente em torno de sua práxis pedagógica podem se dar frente aos respectivos estruturantes dimensionais da práxis em que os sujeitos estão ligados à ideia de coisificação, em que há desconsideração dos contextos socioculturais e à processos educativos lineares. No contexto educativo, o docente em um estado de consciência intransitiva se obscurece em sua prática e desenvolve uma práxis reprodutora/reiterativa havendo, portanto, de acordo com Freire (1987), uma inversão da práxis (intransitiva). Em outras palavras, há 
docentes que ainda se amarram à uma aula científica linear, neutra, acrítica, sintonizada aos preceitos de uma consciência atrelada à práxis reprodutora/reiterativa. Porém, a partir da denúncia do engessamento da prática pedagógica, obscurecida em uma práxis reprodutora/reiterativa e na consciência intransitiva, Freire (1979) nos anuncia que a capacidade inata para transcender é ontológica ao ser humano, e que é possível a ampliação de nossas percepções até alcançarmos o nível da consciência transitiva (da ingênua à crítica). Oliveira e Carvalho (2007) sobre o conceito freireano da consciência transitiva ingênua:

A consciência transitiva ingênua é aquela que amplia o poder de captação e de resposta às sugestões que partem do seu contexto. Seus interesses e preocupações se alongam a esferas bem mais amplas que a simples esfera vital. (Oliveira \& Carvalho, 2007, p. 222).

Assim, consideramos que a consciência transitiva ingênua está ligada aos estruturantes de uma práxis imitativa/mimética em que o docente está em um processo transicional de construção e reconstrução de sua docência, em um movimento dialético intenso, no âmbito do trabalho docente praxiológico, ou seja, esse docente situa-se na dimensão da inversão da práxis (transitiva) em Freire.

Fazer-se docente transcendente à consciência transitiva ingênua em direção à consciência transitiva crítica exige libertar-se e reconstruir-se. Exige do docente compromisso e reconstrução, exige que se supere a consciência intransitiva. À medida que o docente começa a transitar da consciência intransitiva para a consciência transitiva crítica, ele começa também a enxergar a práxis autêntica como direcionamento à Educação Libertadora. Porém, não há salto linear da consciência intransitiva diretamente à consciência crítica e desta à práxis autêntica. Em um processo praxiológico de conscientização, transpor à consciência transitiva crítica em direção à práxis pedagógica autêntica inclui caminhar pela consciência transitiva ingênua e pelo gradiente das dimensões da práxis pedagógica. À medida que se caminha nessa dimensão de tomada de consciência crítica, o docente começa a considerar a participação ativa dos sujeitos do processo educativo, e principalmente, do contexto social. Portanto, alcançar a dimensão da práxis pedagógica autêntica de Freire, requer que o educador acione o nível de consciência crítica em torno de sua prática docente.

Nesta perspectiva, Freire afirma em anúncio, a direção da práxis pedagógica autêntica:

[...] o que nos parecia importante afirmar é que o outro passo, o decisivo, da consciência dominantemente transitivo-ingênua para a dominantemente transitivo-crítica, não daria automaticamente, mas somente por efeito de um trabalho educativo crítico com esta destinação. (Freire, 1967, p. 62).

Nos legitima então que, para o trabalho docente crítico rumo à dimensão da práxis pedagógica autêntica de Freire, é necessário que na prática pedagógica, os sujeitos sejam ativos, os contextos sejam praxiológicos e os processos educativos sejam humanizadores. 


\section{Percurso metodológico}

Imprescindível à esta pesquisa em educação foi seu alinhamento qualitativo a Trivinos (1987), pareando-a ao referencial teórico pautado pelo MHD. Trivinos (1987) define dois enfoques para a pesquisa qualitativa, um fenomenológico e outro marxista. Aqui utilizamos o marxista, com enfoque crítico-participativo e visão históricoestrutural-dialética da realidade social, que parte da necessidade de conhecer através de percepções, reflexões e ações, a realidade para transformá-la, em processos contextuais e dinâmicos.

É imperativo que a práxis, mais que ser entendida e contemplada, seja possível de observação em sua materialidade. Assim, um dos pontos imprescindíveis a esta pesquisa foi conseguir captar as subjetividades em torno do momento praxiológico dos docentes, em suas falas (coletadas em entrevistas) e práticas pedagógicas observadas in loco. Daí a práxis ter sido adotada como categoria a priori nesta pesquisa.

Para a construção dos estruturantes que nos permitiram observar a práxis desenvolvida na prática docente, foi necessário entender o sentido da própria práxis: a ação e a reflexão docente. Para tanto compreendemos que o docente está em movimento dialético entre o desenvolvimento de sua prática pedagógica (ação) e o pensar (reflexão) sobre sua própria prática, o que perpassa pelos níveis de consciência que dela possa ter. Assim, a premissa em torno da materialidade histórico-dialética é a base que nos dá fundamentação para a construção dos estruturantes necessários ao desvelamento da dimensão da práxis pedagógica dos docentes.

Refletindo as obras marxianas, em especial as freireanas, ponderamos que o desvelamento da práxis docente se dá através das relações de interação entre os sujeitos, seus contextos, e de maneira processual. Essas mesmas relações permeiam o trabalho de doutorado de Silva (2004) que permitiu o desvelamento praxiológico curricular de práticas educativas, em diferentes contextos. De tal forma, em Silva (2004), identificamos os três estruturantes que permitem a observação da práxis in loco pelo pesquisador: sujeitos, contextos e processos. Esses estruturantes também foram estabelecidos a priori para a observação participante in loco e para a análise das entrevistas. Essa escolha metodológica está em consonância com as premissas do MHD em que o pesquisador adota lentes a priori para investigar a realidade concreta e seus fenômenos.

Com efeito, a partir desses estruturantes estabelecidos à priori, tendo em vista o objetivo da presente pesquisa de captar em qual dimensão da práxis pedagógica os docentes investigados se situam em relação aos níveis de consciência estabelecidos por Freire (e que foram neste trabalho relacionados às dimensões praxiológicas, conforme figura 2), se fez necessário ir construindo as variações dos estruturantes dimensionais da práxis conforme os dados coletados foram sendo analisados e os resultados de pesquisa foram emergindo. Isso para que o movimento dialético dos docentes investigados em torno das dimensões praxiológicas em que se encontravam no momento da pesquisa, pudesse ser captado e explicitado. 
Em síntese, captar a dimensão da práxis pedagógica de cada docente de Ciências da Natureza foi o ponto central desta pesquisa. Para tanto compreendemos que o docente está em movimento dialético entre o desenvolvimento de sua prática pedagógica e o pensar/refletir sobre sua própria prática, o que perpassa pelos níveis de consciência que dela possa ter.

A coleta de dados se deu através de entrevista estruturada com três perguntas (1. Qual a importância do ensino escolar da Ciência? 2. Em sua sala de aula, como se dá o aprendizado em Ciências? 3. O que é uma boa aula de Ciências?) que buscaram captar as concepções axiológicas, epistemológicas e praxiológicas dos docentes investigados frente à sua prática pedagógica no ensino de Ciências da Natureza e à observação participante, em sala de aula. A síntese contida na Figura 2 embasou tanto a formulação das questões referentes à entrevista dos docentes, como as observações de suas práticas em sala de aula, formando uma base integrada para a análise praxiológica dos dados coletados. A entrevista objetivou trazer à tona a reflexão dos docentes junto ao seu trabalho docente, enquanto a observação participante revelou a dinâmica desenvolvida durante a prática pedagógica, em sala de aula.

No que tange às observações de sala de aula, o ato de ensinar é a estrutura que alinha o desenvolvimento da prática pedagógica do educador à sua reflexão/consciência em torno da mesma, de modo a propiciar elementos que permitam ao pesquisador, a partir do construto teórico formulado, dimensionar a práxis pedagógica de cada docente. A observação da prática pedagógica indica o pareamento ou não às concepções desveladas na entrevista quanto à forma como o docente percebe seu ato de ensino em relação ao desenvolvimento in loco de sua prática pedagógica em Ciências da Natureza.

Participaram efetivamente da pesquisa, e de maneira voluntária, dez professores de Ciências da Natureza, do Ensino Fundamental Anos Finais da rede pública estadual de ensino da Diretoria de Ensino do município de Sorocaba. Entre os docentes houve heterogeneidade de faixa etária, gênero, tempo de magistério e instituição escolar.

A representação $\mathrm{P} 1$ a P10 se refere a cada professor participante da pesquisa. Cada docente foi entrevistado individualmente, sendo suas falas gravadas e transcritas, e sua atuação pedagógica foi observada in loco, em duas aulas consecutivas. Todo processo de coleta de dados foi previamente autorizado pelo docente, pelo gestor de sua instituição escolar, pela respectiva Diretoria de Ensino e pela Secretaria de Educação do Estado de São Paulo, além da aprovação do Comitê de Ética em Pesquisa da Plataforma Brasil, da instituição de ensino superior em que esta pesquisa foi realizada.

No que se refere à metodologia utilizada para a análise dos achados buscamos aproximações com os encaminhamentos teórico-metodológicos da Análise Textual Discursiva (ATD) (Moraes \& Galiazzi, 2011) que tem como finalidade produzir novas compreensões sobre os fenômenos e discursos. A ATD pode ser entendida como um processo auto-organizado de construção e de compreensão, em que novos entendimentos emergem de uma sequência recursiva de três componentes: unitarização, categorização e comunicação. De acordo com os autores, o processo de análise requer o 
uso de informações dispostas em forma de textos que se aproximam do discurso, cujo texto se configura como imersão em processos discursivos na busca por compreensões reconstruídas dos discursos, permitindo a comunicação do que foi apreendido.

O processo de unitarização se inicia com a desconstrução do corpus (conjunto de documentos e registros observacionais a serem analisados), em unidades de sentidos e significados importantes para a finalidade da pesquisa. Em seguida, busca-se fazer a articulação de significados semelhantes em um processo denominado de categorização, construindo relações entre as unidades de base para a formação de conjuntos mais complexos, as categorias. Estas configuram-se em categorias a priori, quando préestabelecidas a partir de teorias já utilizadas na pesquisa, ou categorias emergentes, que emergem no decorrer do processo de unitarização mediante um processo indutivo de caminhar do particular ao geral. Todavia, a categorização pode ser mista, partindo de categorias definidas a priori à luz do referencial teórico que embasa a pesquisa, e à medida que o pesquisador for analisando os achados, novas categorizações podem emergir advindas daquelas estabelecidas à priori. Essa última forma de categorização foi o caso utilizado nesta pesquisa, em que práxis foi adotada como categoria marxiana $a$ priori atrelada aos seus respectivos estruturantes (sujeitos, contextos e processos), a partir dos quais emergiram novas categorias (as variações dos estruturantes dimensionais da práxis atrelados aos níveis de consciência em Freire). Para finalizar a ATD é realizada a etapa de comunicação em que uma nova ordem é estabelecida e novos significados são obtidos pelo olhar do pesquisador, conforme os objetivos propostos, dando origem aos resultados da pesquisa.

\section{Análise da práxis pedagógica em Ciências da Natureza à luz de Freire e dos estruturantes dimensionais da práxis}

Neste tópico consta, além da análise da totalidade das respostas obtidas das entrevistas e das observações em sala de aula, excertos significativos das falas dos docentes. A análise geral das questões da entrevista traz à tona o pensamento reflexivo/ consciência dos docentes de Ciências da Natureza em torno de sua própria dimensão de práxis pedagógica, enquanto a observação in loco desvela sua ação docente, de modo a evidenciar o movimento dialético do grupo, na direção da práxis pedagógica autêntica —, cuja análise foi subsidiada pelos estruturantes da práxis em suas variações.

\section{Sujeitos, Contextos e Processos: estruturantes dimensionais da práxis pedagógica}

As relações que envolvem a práxis no ato de ensino são extremamente complexas. Por sua natureza ontológica, envolvem em seu desenvolvimento cotidiano variáveis que agem diretamente no fazer pedagógico. Para considerar a complexidade nestas variações, se fez necessário compreender em que momento estas se manifestam na práxis, situando-as em suas dimensões. No âmbito desta pesquisa, são considerados três estruturantes praxiológicos atuantes nas variáveis: sujeitos, contextos e processos. 
O estruturante sujeito refere-se à professor e aluno, os quais protagonizam a ação. As relações entre sujeitos, nesta pesquisa, buscaram captar a concepção docente frente ao ensino científico escolar, bem como ao desenvolvimento das interações educadoreducandos durante a prática pedagógica.

O estruturante contexto refere-se ao teor epistemológico na práxis docente. Nele, procurou-se captar as relações que o docente considera no âmbito do currículo prescrito, das normativas educacionais padronizadas, e principalmente, da relevância e utilização do saber social do aluno, em sala de aula.

O estruturante processo é um fator primordial. Se refere ao percurso metodológico do docente direcionado à articulação entre os outros estruturantes praxiológicos de seu ato pedagógico que diz respeito à visão de ensino do professor, seu entendimento sobre como conduzir sua aula de Ciências, sua própria visão axiológica sobre o ensino científico.

$\mathrm{Na}$ totalidade dos resultados obtidos averígua-se que há distintas interações entre as dimensões da práxis pedagógica referentes aos estruturantes sujeitos, contextos e processos, conforme veremos a seguir.

\section{Sujeitos Coisificados}

No contexto da prática pedagógica de Ciências da Natureza, apresentamos alguns exemplos de sujeitos coisificados, coparticipantes e ativos, manifestados durante a pesquisa. O sujeito coisificado aparece na mesma frequência do sujeito coparticipante, enquanto o sujeito ativo é o menos presente.

Acríticos e neutros. Professor e aluno são objetos na práxis educativa. $O$ estruturante sujeito coisificado se mostrou preponderante nos docentes P1, P3, P6 e P7 da pesquisa. Esse olhar docente para o ensino científico mostra que o docente ainda está no nível de consciência intransitiva, sendo que esta interfere diretamente na concepção do papel do sujeito, na prática pedagógica. Ao analisarmos essa parcela do grupo amostral, vemos que a concepção de Ciência que se revela é ligada à forma coadjuvante de compreender o mundo e as relações entre os sujeitos, evidenciando o caráter utilitário e social da Ciência. Algumas falas dos docentes embasam essa análise, ao serem questionados sobre a importância do ensino científico escolar:

A importância é compreender o homem, com suas descobertas, vivência e observação, como ele se encontra nesse planeta. (P1)

O ensino de Ciências, ele traz para o aluno a possibilidade de descobrir o ambiente, aquele onde ele vive, e instigar a possibilidade de ver pequenos e grandes fenômenos que ocorrem no dia a dia. (P3)

Estas falas indicam que a concepção de ensino de Ciências da Natureza para o docente está ligada ao critério da neutralidade, preponderante na dimensão de práxis reprodutora/reiterativa e, portanto, entendida como inversão da práxis em Freire. Isso é revelado pelos verbos ativos mais citados entre os professores: descobrir, esclarecer, 
entender. As frases sugerem que, na totalidade, a visão de ciência do docente entrevistado ainda está atrelada à uma ciência contemplativa, próxima à ciência racionalista e empirista (Chauí, 1996). Dentre as falas, uma que se destaca é:

Tento passar da maneira mais clara para eles (o conteúdo). (P7)

Essa fala transparece que, para o professor entrevistado, o aluno está ligado a um papel passivo no contexto educacional, no qual o professor assume a condição de único sujeito no processo, "passando" o conhecimento científico ao aprendente. A aproximação dessa fala com a concepção de educação bancária caracterizada por Freire (1987) é nítida, já que nela se explicita que o aluno é sujeito coisificado, no processo educacional. Coisificação, para Freire (1987), é um processo desumanizante, alienador e opressor das massas, que desconsidera o homem ontologicamente humano e o torna objeto de adaptação social, refutando o diálogo entre os pares.

Em lugar de comunicar-se, o educador faz "comunicados" e depósitos que os educandos, meras incidências, recebem pacientemente, memorizam e repetem. Eis aí a concepção bancária de educação em que a única margem de ação que se oferece aos educadores é a de receberem os depósitos, guardá-los e arquivá-los. (Freire, 1987, p. 33)

Freire (1987) nos remete ao aprisionamento dos sujeitos, quando coisificados na condição de objetos, no processo educativo:

$\mathrm{Na}$ medida em que, para dominar, se esforçam por deter a ânsia de busca, a inquietação, o poder de criar, que caracteriza a vida, os opressores matam a vida. Daí que vão se apropriando, cada vez mais, da ciência também, como instrumento para suas finalidades. Da tecnologia, como forma indiscutível da manutenção da "ordem" opressora, com o qual esmagam, manipulam. Os oprimidos, como quase "coisas", não têm finalidades. As suas, são as finalidades que lhes prescrevem os opressores. (Freire, 1987, p. 26)

Entre o sujeito coisificado, amarrado, contemplativo, aproximado das dimensões da práxis reprodutora/reiterativa desveladas por Lefebvre (1975) e Vázquez (1977), e, o sujeito ativo, atuante e transformador, pertinente à práxis pedagógica autêntica de Freire (1987), há um sujeito que os medeia, aqui denominado como sujeito coparticipante.

\section{Sujeitos Coparticipantes}

Em suas falas, os docentes P5, P8, P9 e P10 indicam que suas reflexões buscam sujeitos ativos no processo ensino-aprendizagem. Porém, em sala de aula, o papel de seus alunos é destinado à coparticipação.

O sujeito coparticipante refere-se à construção conjunta de papéis educativos onde professor e alunos são sujeitos no processo, podendo haver criticidade, mas em imitação à práxis transformadora/criadora/autêntica. Na coparticipação, o educando leva para o ambiente escolar científico, suas dúvidas, sua necessidade de aprender sobre o 
ambiente em que vive, assim como sua própria manifestação sobre ele, e as expõe, tendo voz nesse processo. O coparticipante é o sujeito cuja concepção de ensino científico se encontra em desconstrução, caminhando para a superação da Ciência como fenômeno contemplativo humano. O professor coparticipante inicia o processo de desnudar-se do papel de mediador cognitivo, que o coisifica como transmissor do conhecimento científico, e começa a inserir, em sua prática, a voz dos alunos como participantes. Alunos e docentes como sujeitos coparticipantes, contemplam suas atuações no contexto do processo ensino-aprendizagem, porém, no que se refere aos avanços, na reconstrução de seus papéis, ainda transitam, caminhando ou não ao patamar da práxis pedagógica autêntica, que culmina na emancipação do sujeito. Se as dúvidas e o senso comum dos alunos se tornam reflexivos entre eles e o professor, de modo a caminharem rumo à sua superação, torna-se possível continuar na direção da aproximação dos sujeitos ativos. Por outro lado, se não se superam as dúvidas e limites explicativos dos educandos, se estagna o nível de consciência do sujeito, permanecendo, este, em uma concepção ingênua de conhecimento, no âmbito da dimensão imitativa/mimética da práxis pedagógica. A fala do docente P9 revela o repensar pedagógico frente ao ensino científico:

A disciplina ciências no ensino escolar auxilia o pensar, o criar soluções relacionadas ao homem com o meio ambiente, eleva a autoestima, a criatividade, aprimora o senso crítico e principalmente as habilidades de pesquisas e de autonomia. (P9)

Estudar ciências em todos os níveis de ensino é essencial para desenvolver o senso crítico do indivíduo, aguçar sua criatividade e proporcionar uma visão ampla em todos os contextos. (P10)

Enuncia-se nas falas dos docentes, a reflexão da concepção de ensino científico escolar. Porém, apesar das falas anunciarem a ideia de transformar pela criticidade, a ação docente precisa acompanhar essa concepção para o engajamento da prática pedagógica, na busca pela práxis pedagógica autêntica. As concepções dos docentes desse grupo sobre suas práticas se aproximam da dimensão da práxis pedagógica autêntica, mas sua prática continua atrelada à dimensão de inversão da práxis e ao nível da consciência transitiva ingênua. Apesar de as concepções dos docentes sobre a participação dos educandos serem de sujeitos ativos no processo, essa se dá de maneira não crítica. Assim, os docentes refletem sobre uma concepção de ensino científico que busque significância ao aluno (intenção manifestada em suas falas), mas ainda se prendem às reflexões técnicas e instrumentais ligadas a esta significação (ação observada em suas aulas). Assim, os docentes, apesar de agora serem vigorosamente reflexivos, ainda são contemplativos no contexto de sua prática pedagógica, mantendo-se, portanto, no nível de consciência transitiva ingênua, dimensionados na práxis imitativa/mimética.

Nesse estruturante da práxis pedagógica há que se ponderar que o aluno ganhe voz no espaço da sala de aula, como sujeito de seu próprio processo ensino-aprendizagem. Analisando os dados compilados vemos que isso ocorre de maneira contínua nas 
relações interativas professor-aluno. Tal continuidade se dá quando consideramos que é mediante o processo ensino-aprendizagem que os sujeitos coisificados transitam para coparticipantes na direção de se tornarem sujeitos ativos frente à uma práxis pedagógica autêntica e transformadora, resultante de uma construção histórica constante das relações educativas. A transição se dá à medida em que o nível de consciência dos sujeitos se eleva, em que a práxis entre os homens e mulheres se alinham, e em que os sujeitos se reconstroem mutuamente em seus papéis, no contexto das relações educativas. Um novo olhar do professor sobre si como docente e sobre o outro como aluno, passa pela interface de se deslocar da concepção de mediação exclusiva do conhecimento científico, para a construção do conhecimento científico de forma conjunta.

\section{Sujeito Ativo}

Esse é o sujeito transformador, produtor do seu processo de ensino-aprendizagem, sendo considerados sujeitos tanto educadores quanto educandos. Na concepção de ensino científico do docente $\mathrm{P} 4$, os educandos podem protagonizar o próprio processo de construção do conhecimento científico, aproximam-se fortemente do nível de consciência transitiva crítica que leva à dimensão da práxis pedagógica autêntica, integrando o aluno como sujeito ativo e transformador.

Assim, a concepção científica do professor vai além da epistemologia empirista, caminhando para um modo de ensino científico que busca a concepção dialética de Ciência, que supera a reflexão e busca a ação de transformação social e emancipatória dos educandos, pela apreensão do conhecimento científico voltado à transformação da realidade concreta. Apresentamos a fala do docente sobre a importância do ensino científico escolar, a qual foi alinhada à sua ação observada em sala de aula:

Para sistematizar todo o conhecimento acumulado pelo ser humano, pela humanidade, todo processo histórico de elaboração do conhecimento, da natureza, da ciência, de como que a ciência foi elaborando os conhecimentos, a partir de estudos, mas também de como a ciência está presente no cotidiano e na realidade para entender a vida em si dos próprios educandos, no seu cotidiano, inserir isso nesse contexto e em diferentes contextos, para se analisar de modo crítico. (P4)

$\mathrm{O}$ alinhamento entre as falas e ações pedagógicas do participante aproximam os estruturantes da práxis ao polo contrário à práxis reprodutora/reiterativa, ou seja, à práxis transformadora/criadora/autêntica. Em suas reflexões e ações, há busca constante de sujeitos ativos, que, no processo educativo buscam a superação da inversão da práxis e o direcionamento à práxis pedagógica autêntica. Na prática desse docente ficou evidente a busca pela superação do ensino científico proposto nos moldes curriculares tradicionais, pela Secretaria Estadual de Educação, ou seja, a busca por um ensino significativo voltado ao contexto social em que os alunos se façam sujeitos ativos. 


\section{Contextos}

$\mathrm{O}$ ato de ensinar se dá pelo movimento de ação-reflexão-ação, que está em constante movimento dialético de reconstrução, levando em consideração contextos, sujeitos e processos, ou seja, considerando a própria práxis. Contextos educacionais agem como mediadores epistemológicos, implicando fundamentalmente na ação ativa da práxis pedagógica autêntica. O distanciamento que separa a interação dos sujeitos envolvidos no processo ensino-aprendizagem rumo ao seu caminhar em direção ao sujeito ativo e à práxis pedagógica autêntica, pode ser consequência do tratamento do contexto em que a prática pedagógica de Ensino de Ciências da Natureza vem sendo desenvolvida. Daí explicitarmos os contextos das práticas pedagógicas dos docentes.

\section{Contexto Empírico}

P1, P3, P6 e P7 são os docentes que refletem suas falas e ações alinhadas a um contexto empírico. O contexto educativo empírico se refere àquele que foi selecionado à priori e à revelia dos sujeitos diretamente envolvidos. Em contextos empíricos, tanto professor quanto aluno - os sujeitos do processo educativo - não são ativos. Os contextos que se expressaram na pesquisa apontam uma predominância da concepção linear e empírica do ensino científico, uma vez que se aproximam de uma relação ensinoaprendizagem contemplativa e neutra. P3 e P7 acerca da questão sobre como se dá a aprendizagem de Ciências em sala de aula respondem:

Procuro diversificar sempre a aula, trazer coisas diferentes para não deixar ter monotonia, para instigar e não ficar cansativo, o conteúdo teórico é sempre importante para a base sobre o tema, trago experimentos e atividades para ele produzir algo, como maquete ou jogos, para entender o tema tratado. (P3).

Por aula expositiva e dialógica, em duplas, ou em laboratório. (P7)

A questão visa captar o entendimento docente sobre o papel do contexto na prática pedagógica. Nas falas e práticas em sala de aula desse grupo revelou-se a aproximação a um contexto empírico, alinhado à dimensão da práxis reprodutora/reiterativa. Os pilares do contexto empírico identificado no grupo encontram-se abrigados em um nível de consciência intransitiva, mantendo inerte o movimento dialético da prática docente, de modo a impossibilitar a superação da dimensão de inversão da práxis rumo à práxis pedagógica autêntica.

\section{Contexto Reflexivo}

A reflexão isolada não leva à ação praxiológica. Em um contexto reflexivo, os sujeitos podem assumir coparticipação, quando ouvidos quanto às suas curiosidades individuais, técnicas e até ingênuas. Mas, pelo docente ainda manter um elo pedagógico à uma condição linear e técnica do ensino de ciências, o contexto ainda está condicionado ao viés empírico, engessando o sujeito, total ou parcialmente, na coisificação, impedindo seu processo criativo. 
Os docentes P5, P8, P9 e P10 têm uma movimentação dialética diversa dos docentes relativos ao contexto empírico, já que suas falas apontam para um mediador epistemológico em com contexto de reflexão, porém a prática está voltada epistemologicamente ao contexto empírico, de ensino linear. Nesta parcela, as ações observadas em sala de aula contrapõem-se às suas falas. Exemplo disto está na fala de P10, com base no questionamento sobre como o aluno aprende em sua aula de Ciências, cuja aula observada limitou-se ao desenvolvimento de atividades/exercícios previstos na grade curricular padrão.

O aluno é instigado a contextualizar as teorias em seus mais diversos aspectos, para que ele entenda que faz parte de todo o processo, mesmo que indiretamente. Ele também é estimulado a usar sua criatividade em diversos momentos, assim como desenvolver sua criticidade sobre diversos assuntos. (P10)

Nitidamente, o docente evidencia seu pensar sobre a aprendizagem científica, seu papel e significância para o aluno, como movimento dialético abstrato. Já em sua ação pedagógica, o docente está amarrado a contextos pré-escolhidos, padronizados, conformados às regras e trâmites curriculares estabelecidos, e que desconsideram as peculiaridades dos sujeitos da prática pedagógica.

Essa contradição entre pensamento e ação pedagógica atuante é um indicativo que, nesse grupo, a consciência intransitiva foi superada pela consciência transitiva ingênua, de modo a continuar se movendo em direção à consciência transitiva crítica, em pleno processo de construção e reconstrução. A ação do movimento dialético começa a mobilizar inicialmente a reflexão do pensamento docente junto a uma concepção voltada para uma práxis autêntica. P5, P8, P9 e P10 representam uma parcela dos docentes imersos nessa situação, aproximados a uma dimensão imitativa/mimética de práxis pedagógica, análoga ao termo freireano inversão da práxis. Sobre esta transição expressa-nos Freire (1987):

O novo da revolução nasce da sociedade velha, opressora, que foi superada. Daí que a chegada ao poder que continua processo, seja apenas, como antes dissemos, um momento decisivo deste.

Por isto é que, numa visão dinâmica e não estática da revolução, ela não tenha um antes e um depois absolutos, de que a chegada ao poder fosse o ponto de divisão.

Gerando-se nas condições objetivas, o que busca é a superação da situação opressora com a instauração de uma sociedade de homens (e mulheres) em processo de permanente libertação.

O sentido pedagógico, dialógico, da revolução, que a faz revolução cultural também, tem de acompanhá-la em todas as suas fases. (Freire, 1987, p. 77)

O início do movimento dialético que aciona a reflexão do contexto como 
mediador epistêmico da práxis, ativa a transposição da consciência intransitiva de uma práxis reprodutora/reiterativa para o nível de consciência transitiva ingênua, ligado à práxis imitativa/mimética, e se faz fundamental para o início da superação da dimensão de inversão da práxis e aproximação à práxis pedagógica autêntica, de Freire.

\section{Contexto Praxiológico}

O contexto praxiológico como mediador epistemológico da práxis docente emerge da contradição social. Ao contrário do que se vê no contexto reflexivo, a reflexão docente culmina em ação praxiológica. P2 e P4 foram os docentes que mais se aproximaram da práxis pedagógica autêntica de Freire, considerando o estruturante contexto. A percepção em torno do contexto praxiológico da prática dos referidos docentes sobre o que seria uma boa aula de Ciências, assim se manifesta:

Uma boa aula de ciências é o que causa estranhamento do que sempre se pensou ou conformou, e aí ele passa a perceber que ele passa a saber. Se não tiver relevância social é inútil. (P2)

Considerando uma perspectiva mais crítica, uma boa aula deve fazer o estudante explorar a sua realidade, e atuar nessa realidade. (P4)

Situamos P2 em uma dimensão imitativa/mimética de práxis pedagógica rumo à práxis transformadora de Marx, e à práxis pedagógica autêntica de Freire. O participante P2 demonstrou afinidade, familiaridade e proximidade com a práxis autêntica, em quase todos os quesitos analisados, alinhando seu fazer pedagógico relativo ao ato de ensinar, às suas reflexões, de maneira crítica, contextualizada e problematizadora. Suas falas perpassam além do contexto, os estruturantes sujeito e processo, ora utilizando reflexões que se aproximam de um referencial de práxis de dimensão reprodutora/reiterativa, mas, preferencialmente, ora alinhadas à dimensão da práxis pedagógica autêntica, em que suas reflexões correspondem diretamente à sua ação pedagógica. Assim, P2, em sua movimentação dialética rumo à dimensão praxiológica autêntica busca maior alinhamento a esta, apontando para um nível de consciência de forte aproximação à consciência transitiva crítica.

$\mathrm{O}$ docente $\mathrm{P} 4$ foi o que evidenciou maior aproximação com a práxis pedagógica autêntica, articulando reflexão e ação em seu ato pedagógico. Fala e ação em P4 busca o desassossego dos educandos quanto às acomodações científicas pré-estabelecidas em torno de concepções e conceitos, utilizando-se do contexto social local como parâmetro para o ensino das ciências da natureza, buscando em sua própria inconclusão, como educador, seu constante refazer pedagógico. $\mathrm{O}$ alinhamento entre as falas e ações pedagógicas do docente aproximam os estruturantes da práxis ao polo contrário à práxis reprodutora/reiterativa, ou seja, à práxis pedagógica autêntica. Em suas reflexões e ações há busca constante de sujeitos ativos, de processos humanizadores, e principalmente, de 
contextos sociais pertinentes com a ambientação real dos educandos. Em sua prática, foi possível observar in loco a busca docente pela superação do ensino científico tradicional.

Freire (1987) faz destaques acerca dos contextos do processo educativo:

Simplesmente, não podemos chegar aos operários, urbanos ou camponeses, estes, de modo geral, imersos num contexto colonial quase umbilicalmente ligados ao mundo da natureza de que se sentem mais partes que transformadores, para, à maneira da educação 'bancária', entregar-lhes 'conhecimento' ou impor-lhes um modelo de bom homem, contido no programa cujo conteúdo nós mesmos organizamos. (Freire, 1987, p. 48)

O professor, mesmo na intencionalidade do avanço participativo dos alunos, se não se desvincular da amarra empírica da contextualização nas aulas de Ciências, dificulta a superação das curiosidades ingênuas de seus alunos e alunas, assim como as suas próprias. Como sujeitos do processo, não se alcança e supera sem a busca científica educacional, questões geradas no senso comum, e se chega às discussões epistemológicas praxiológicas, se, a prática do professor, ao dar preferência e relevância ao contexto empírico, impeça o alcance do contexto praxiológico, ao não considerar os fatores socioculturais relevantes ao aluno.

\section{Processos}

O caminho percorrido pedagogicamente pelo docente refere-se ao processo educativo de ensino. Muito além da escolha instrumental de métodos para o desenvolvimento da aula, o docente demonstra no processo educativo o desdobramento de sua ação e suas afinidades com a dimensão da práxis ao qual se encontra. O processo é a liga que une os estruturantes sujeito e contexto, podendo otimizar o movimento dialético para a aproximação docente à uma práxis autêntica. Observamos um evidente vigor cientificista nos processos de ensino-aprendizagem em Ciências da Natureza por parte dos docentes investigados. O direcionamento instrumentalizador contido nas falas e práticas dos/as docentes, ao afirmarem que o aluno aprende por métodos estabelecidos, experimentos e uso de materiais físicos, como livros didáticos, instrumentos laboratoriais, recursos tecnológicos, é uma constante. A ênfase docente no método de ensino de Ciências instrumental em um contexto empírico, mostra que o ensino empírico e cientificista dirige os critérios que orientam o processo educativo, tornando o ensino de ciências um produto em si mesmo.

\section{Processo Educativo Linear}

Trata-se de um processo educativo de caráter linear, acrítico, mecânico, transmissor de informação, neutro, representado pelos docentes P1, P3 e P7. Na questão “Em sua sala de aula, como se dá o aprendizado em Ciências?” algumas falas destes participantes representam essa interpretação:

O aluno aprende de tanto eu falar, usar o dicionário, usar internet. (P1) 
O conteúdo teórico é sempre importante para a base sobre o tema, trago experimentos e atividades. (P3)

É um processo educativo ligado a reflexão sobre materiais e métodos, à um processo educativo linear e não a um paradigma metodológico que direcione à um processo emancipatório e transformador, já que nas falas há a presença de um ensino pautado na neutralidade, descomprometido com a historicidade científica dos contextos sociais, descompromissado com as inter-relações sociais da ciência, mas em plena valorização instrumental. Revela-se nas respostas deste grupo, que a relação reflexãoação docente está em sintonia, mas relativa a um ensino científico pautado em uma concepção de ciência não crítica e neutra. A reflexão docente é constante, mas não sobre a própria prática. Ao invés disso, direciona-se a reflexão para o aprimoramento técnico do ensino científico, para uma reflexão de métodos instrumentais mais eficazes para a apreensão de conceitos, fórmulas e concepções lógicas e matemáticas, no contexto do ensino de Ciências da Natureza.

O docente P3 demonstra isso pela sua fala, focada na diversidade instrumental na busca de uma aula diversificada e não monótona ao aluno, para que a aula se torne "interessante". Temos aí um ponto de atenção entre a fala e a ação do professor. Observada sua prática em sala de aula, no desenvolvimento do processo educativo por esse docente, emergiu o uso de uma diversidade de recursos didático-pedagógicos, empregados em uma conceituação científica que não ultrapassa o nível de consciência intransitiva e o senso comum que a sala de aula pode gerar, buscando em um contexto curricular pré-definido, uma maneira de abrandamento do conteúdo escolar, em uma nova roupagem metódica, prendendo-se à ideias e concepções que se distanciam de uma educação científica emancipatória. Não há sentido e significado científico que supere a aula quando o rigor docente se prende, de maneira intensa, aos instrumentos que desenvolvem apenas o método, de maneira técnica.

Não podemos desconsiderar os recursos didático-pedagógicos de utilização diária do professor como sendo facilitadores de seu trabalho educacional. Há um histórico de pesquisas científicas que os consideram como atenuante do cotidiano escolar, no ensino científico (Bachelard, 1968; Cunha, 1988; Gomes \& Friedrich, 2001; Mehes \& Maistro, 2011). Contudo, há de se considerar que o uso de materiais lúdico, tecnológico e experimental está alinhado à uma perspectiva pedagógica, conforme seu mediador epistêmico (Mallmann, 2008; Moraes, 2004). Assim, materiais utilizados no âmbito de um percurso metodológico dirigido ao ensino científico dialético, auxiliarão na compreensão dialética do contexto tratado, seja ele de cunho empírico ou transformador. A escolha do direcionamento do percurso metodológico, e não só do uso de seus recursos didáticos, aproximam ou distanciam os docentes no contexto do gradiente dimensional de práxis aqui considerado, rumo à práxis pedagógica autêntica de Freire.

As falas de P1, P3 e P7 se alinham ao desenvolvimento do processo ensinoaprendizagem em suas aulas, que se voltam à finalidade do ensino científico pelo resultado 
produzido. Para eles, o produto que seu aluno propôs ao final da aula mostra-se de superior importância ao processo de ensino-aprendizagem. A fala do docente P7 para uma boa aula de Ciências reflete o objetivo de seu processo pedagógico:

É de que, ao final, todos os alunos produzam o resultado esperado. (P7).

Assim, a preocupação docente com o produto da aprendizagem deixa para segundo plano o desenvolvimento processual do ensino científico, desmerecendo seu valor cognitivo, alienando e coisificando professor e aluno, e posiciona a Ciência como um fator à margem da totalidade social (Praia et al., 2007).

Processo educativo linear é o estruturante que remete à dimensão reprodutora/ reiterativa da práxis, em cuja dimensão o grupo de docentes P1, P3 e P7 evidencia forte afinidade pedagógica. Ao voltarmos o olhar aos outros estruturantes da práxis que guiam esses docentes, observamos que são eles próprios que não reconhecem seus alunos como sujeitos da ação, que estão presos ao contexto curricular pré-definido, e que se pautam em um processo educativo amarrado à educação científica neutra. $\mathrm{O}$ movimento dialético de sua prática está em inércia atrelada ao nível de consciência intransitiva, conduzindo à uma dimensão de inversão da práxis pedagógica.

\section{Processo Educativo Espelhado}

Por seu caráter imitativo, o espelhar-se pode ser problematizador no âmbito das interações socioculturais, participativo, político e histórico, mas não reflete a dimensão da práxis autêntica, por não ser inédito.

Há de se considerar que o grupo de docentes investigados não foi homogêneo. Logo, apesar do processo educativo preponderantemente observado nas falas dos docentes estar ligado a linearidade e neutralidade científica, ligados à dimensão reprodutiva/reiterativa da práxis, observamos os docentes P5, P6, P8, P9, P10 que em sala de aula buscavam um processo educativo significativo para a construção da criticidade, demonstrando intencionalidade na direção da práxis pedagógica autêntica. Esta face do estruturante da práxis relativa ao processo educativo denominado espelhado, reflete a busca docente à dimensão da práxis pedagógica autêntica. A prática de um processo educativo espelhado que imita ou procura aproximar-se de uma prática docente praxiológica, é essencial no processo de superação das práticas lineares, atreladas às práticas pedagógicas empíricas. Espelhar-se à uma prática transformadora ou prática educativa autêntica pelas premissas freireanas, é buscar a sua compreensão processual. O processo espelhado dissemina práticas de transformações, reinventando na parcialidade ou totalidade, processos educativos voltados à práxis pedagógica autêntica. O processo educativo espelhado é parte do processo contínuo de construção da consciência rumo à consciência transitiva crítica da práxis, pelos docentes, momento em que o professor passa de um processo educativo linear para um processo educativo humanizador. Assim:

O que une e separa o antigo do novo é o fato de ambos serem respostas a uma interpelação que provém do objeto; são semelhanças reconstruídas, são respostas 
singulares e históricas, em que o que estava petrificado e alienado se torna eloqüente, através da participação ativa da expressão e da construção artística. A própria razão se torna mimética no estremecimento da criação do novo. (Zuin et al., 1999, p. 106).

Para se chegar a um processo educativo humanizador, é inevitável caminhar pelo espelhamento que o reflete. Assim como, na construção do estruturante sujeito, não se salta de uma condição histórica de doutrinação e alienação, pautada em um processo educativo linear para o processo educativo humanizador, é preciso construir o caminho para isso. Assim, o processo ensino-aprendizagem necessita passar pela contínua desconstrução e reconstrução, o que foi observado no grupo de docentes investigados, que, ao caminharem pelo processo educativo espelhado, aproximam-se de um processo educativo humanizador.

Porém, o caminhar é íngreme. Em sala de aula, o grupo docente situado no processo educativo espelhado apontou que o professor de Ciências ainda se prende a métodos instrumentais como trâmite indispensável para o alcance de novos processos de ensino científico significativo, associando os mais diversos tipos de ferramentas e recursos "pedagógicos" no seu processo educativo: aula invertida, gameficação, aprendizagem por estações, educação maker, relativa à proposta de novos modelos de aula, tida como metodologias inovadoras de ensino-aprendizagem, aplicadas à educação escolar.

Porém, o caminho criativo, inovador e reflexivo do professor ainda se apega no uso do método novo, que, pelo docente é identificado como inovador, mas não alcança sua reconstrução metodológica. Assim, a maioria dos docentes ainda se baseia em percursos ligados ao lúdico, desarticulando a aula de Ciências do plano contextualizado, da realidade concreta e social. Calha nossa observação ao pensamento freireano:

É próprio do pensar certo a disponibilidade ao risco, a aceitação do novo que não pode ser negado ou acolhido só porque é novo, assim como o critério de recusa ao velho não é apenas o cronológico. $\mathrm{O}$ velho que preserva sua validade ou que encarna uma tradição ou marca uma presença no tempo continua novo. (Freire, 1996, p. 17).

Pela própria constância do movimento dialético, o espelhamento se faz inconcluso. $\mathrm{O} / \mathrm{a}$ docente de Ciências considera por diversas vezes, questões referentes ao contexto social, à realidade dos alunos, debate, discute com eles assuntos relevantes no contexto de sua aula. Essa situação, embora tenha sido observada nesta pesquisa, evidencia que o docente não coloca o contexto em conflito cognitivo para a transformação da realidade social. Em contrapartida, acolhe no seu processo educativo o método, o instrumental, como se este contemplasse na sua totalidade uma forma significativa de ensino científico. Reflete sobre esse processo pedagógico, mas mantém a ingenuidade em torno da ideia de que ao se utilizar de novas tecnologias e novos recursos didáticos está inovando significativamente. O docente, ao acreditar que está inovando nos métodos, sem 
contextualizá-lo e trazê-lo à realidade material dos alunos, ainda estará arraigado aos modelos tradicionais de ensino científico, acrítico, antidialético. Sobre isso, nos alerta Silva:

É nesse sentido que estabelecer critérios para a legitimidade das inovações envolve parâmetros éticos, a consciência crítica e a disponibilidade para a intersubjetividade, o compartilhar dialógico. (Silva, 2004, p. 318)

Ao findarmos este estágio do processo educativo como estruturante da práxis, observamos a dinâmica do movimento dialético ativo na prática docente. No processo educativo espelhado, a movimentação dos estruturantes se dá em sintonia à dimensão imitativa/mimética da práxis. Nesse momento, o docente busca pela ruptura com a inversão da práxis, que o mantém na inércia trazida pela práxis reprodutora/reiterativa. Foi observado no grupo de docentes que caminharam por este processo, a ruptura do papel coisificado dos sujeitos. Em sua maioria, o docente que está percorrendo esse caminho busca a parceria do aluno para a construção da aprendizagem, trazendo-o para o papel de protagonista, em sua aula. Reconhece o aluno como agente produtor ativo de seu próprio conhecimento, mas como ainda está em um processo da construção de sua consciência transitiva, de ingênua para crítica, ainda não consegue sair de um contexto que não seja o empírico em que está imerso. Assim, sua práxis ainda é mimética/imitativa, já que o movimento de seus estruturantes não está em sintonia dialética com a práxis pedagógica autêntica.

\section{Processo Educativo Humanizador}

Trata-se de um processo educativo problematizador no âmbito das interações socioculturais, conscientizador, participativo, transformador político e histórico.

Os docentes $\mathrm{P} 2$ e $\mathrm{P} 4$ observados em sala de aula revelaram posturas pedagógicas na direção de um processo educativo humanizador, significativo para a construção da criticidade, demonstrando intencionalidade à práxis pedagógica autêntica. Para esses docentes, a proximidade à práxis pedagógica autêntica converge, mas fluem em gradientes diferentes de aproximação à ela - o que foi evidenciado quando estes docentes respondem a mesma questão para a aprendizagem dos alunos em sua aula frente ao contexto em que se encontram:

O cientista não é um gênio, as teorias mudam, falo para o aluno que um dia ele também pode mudar uma teoria. (P2) 
Durante as aulas passo essas atividades com esses recursos diversos para alcançar meus objetivos, dos conhecimentos que eu pretendo, tanto de conteúdo, mas também de conhecimento de questões locais, trabalho com eles texto jornalísticos, internet, alguns textos são falsos, outros são reais, o que tá acontecendo na região. (P4)

Para os docentes, a ciência é processual, uma construção histórica, dialética e contraditória. As verdades científicas não são absolutas, e podem ser contestadas, revistas, modificadas, na interação com sua prática docente. $\mathrm{O}$ docente P2 difere de P4, pois ainda mantém em alguns momentos de sua prática o elo à um contexto linear, o que o detém ainda ao processo educativo espelhado. Porém, P2 se destaca, já que trata o aluno, na maioria do processo educativo, como sujeito protagonista, o que o aproxima de um patamar mais próximo da práxis pedagógica autêntica do que os demais docentes que estão no processo educativo espelhado. Já o P4 considera o contexto social na totalidade de seu processo educativo. $\mathrm{P} 2$ ao reconhecer que o aluno pode modificar uma teoria científica, e $\mathrm{P} 4$, que reconhece que os estudantes podem protagonizar o próprio conhecimento científico, aproximam-se fortemente do nível de consciência transitiva crítica e da práxis pedagógica autêntica, integrando o aluno no processo educativo humanizador, como sujeito ativo e transformador, participante da construção do conhecimento científico escolar. Assim, a concepção científica do professor vai além da epistemologia empirista, caminhando para um modo de ensino científico que busca a concepção dialética de Ciência, que supera a reflexão e busca a ação de transformação social e emancipatória dos educandos, pela apreensão do conhecimento científico voltado à transformação da realidade concreta. Este direcionamento educacional revela que há uma parcela docente que prima por um processo educativo de sentido e significado praxiológico, embasado por uma práxis pedagógica de dimensão autêntica.

Assim, chegamos à figura 4 que representa a totalidade dos resultados obtidos acerca dos estruturantes dimensionais da práxis pedagógica dos docentes investigados (representados por P1 a P10) a partir dos dados coletados via entrevistas (representados pela cor azul) e via observação participante in loco (representados pela cor vermelha). Desta forma, a figura 4 dimensiona os docentes investigados em cada variante estruturadora da práxis, a partir das análises dos dados obtidos. 
Figura 4. Síntese dos estruturantes da práxis manifestados a partir de cada docente

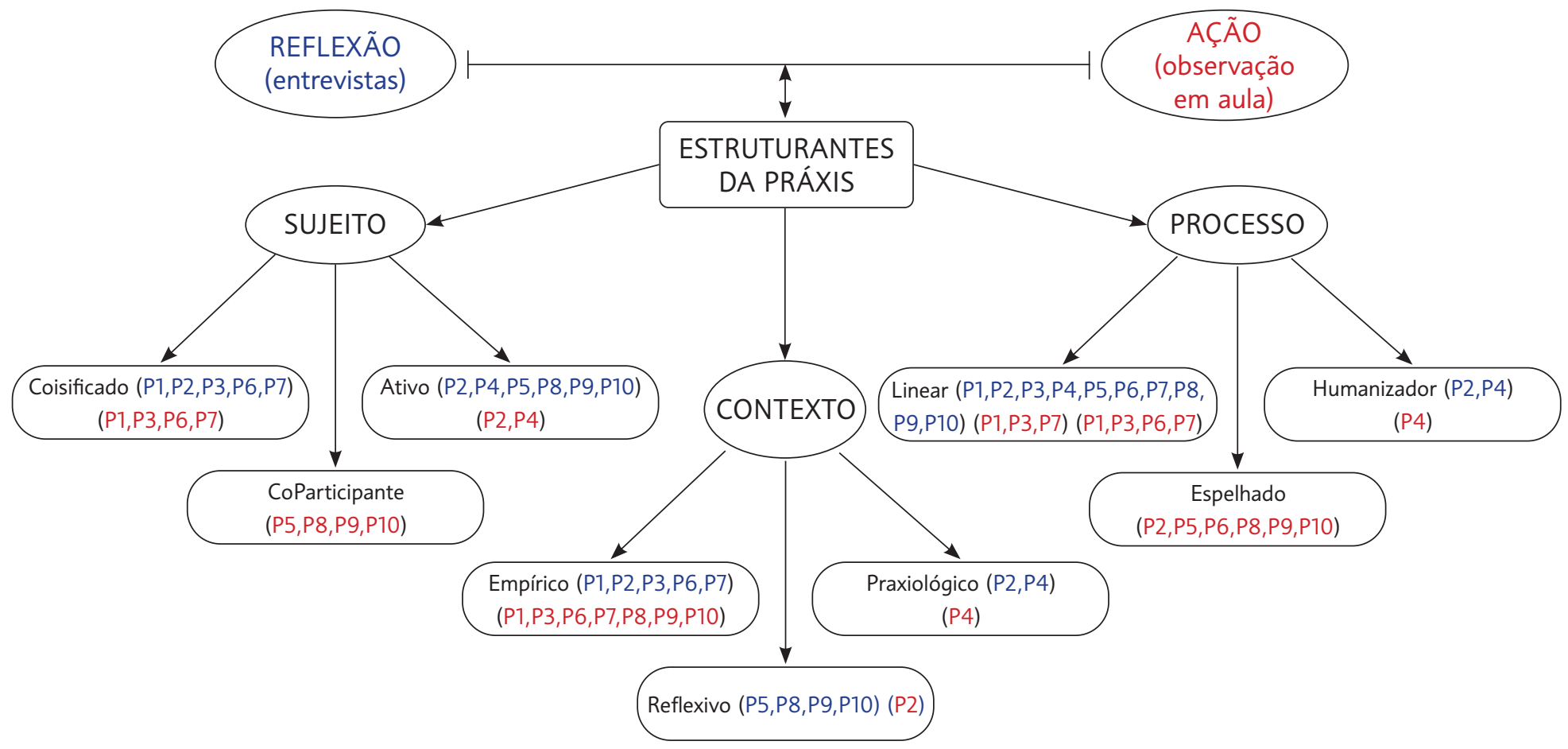

Fonte: Elaboração própria.

Em síntese, os resultados obtidos frente ao movimento dialético da tríade prática pedagógica dos professores, os respectivos níveis de consciência de Freire e as possíveis dimensões da práxis pedagógica encontram-se sistematizados na figura 5.

Figura 5. Síntese da aproximação das dimensões da práxis atreladas às práticas pedagógicas dos docentes

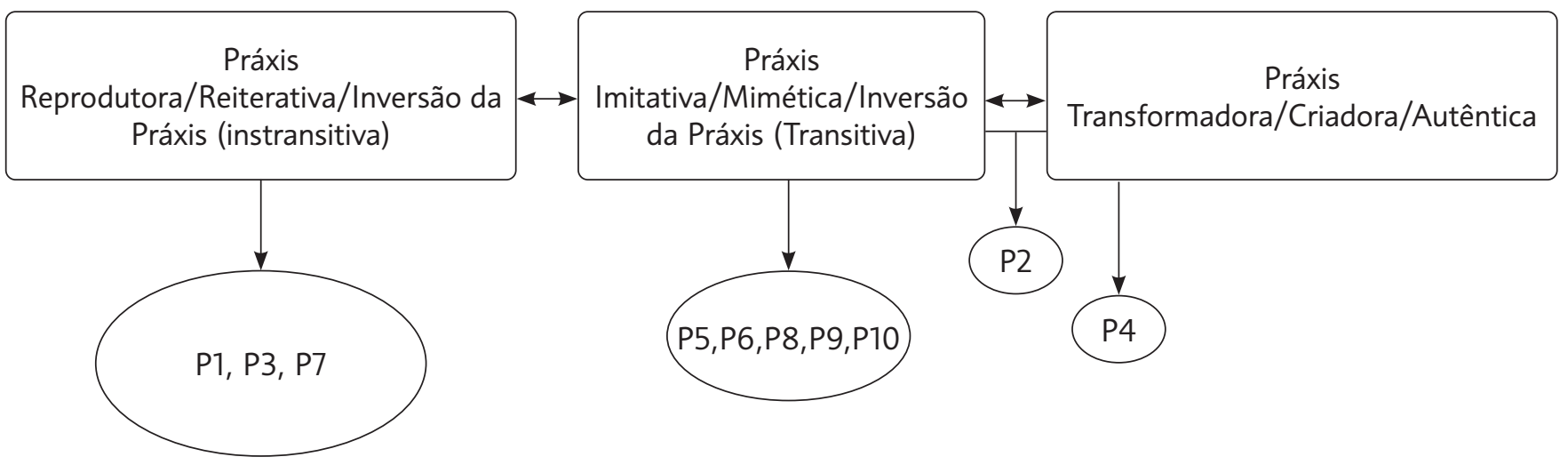

Fonte: Elaboração própria.

Na figura acima encontra-se a síntese das relações dos estruturantes da práxis em seu movimento dialético rumo à práxis pedagógica autêntica, do grupo de dez docentes de Ensino de Ciências da Natureza, da rede pública estadual de educação de um município paulista. Os resultados obtidos apontam que a dimensão da práxis pedagógica em que 
cada docente se situa depende do movimento dialógico em torno dos estruturantes de sua prática pedagógica atrelado aos níveis de consciência dos docentes em torno de sua prática, ora situada na dimensão da inversão da práxis, ora em processo de transição desta para a práxis autêntica, ora mais próxima da práxis pedagógica autêntica. Assim, P4 é o que mais se aproxima da dimensão autêntica de práxis pedagógica. Indispensável se faz, a partir dos dados analisados, a percepção da busca constante dos docentes de Ciências da Natureza, de uma prática de maior proximidade à transformação social, no contexto de uma Educação Libertadora (Freire, 1987), cuja criticidade se faz necessária para que esta ação ocorra.

Críticos seremos, verdadeiros, se vivermos a plenitude da práxis. Isto é, se nossa ação involucra uma crítica reflexão que, organizando cada vez o pensar, nos leva a superar um conhecimento estritamente ingênuo da realidade. Este precisa alcançar um nível superior, com que os homens cheguem à razão da realidade. Mas isto exige um pensar constante, que não pode ser negado às massas populares, se o objetivo visado é a libertação. (Freire, 1987, p. 73)

$\mathrm{Na}$ síntese dos resultados, vemos que a plenitude da práxis é a plenitude pedagógica. Para além de uma ciência escolar conceitual e acadêmica, se faz necessária o ensino científico praxiológico, de cunho autêntico e transformador. Por isso, o constante pensar pedagógico, e para isso, a constante movimentação da consciência e da dimensão da práxis rumo à prática pedagógica autêntica.

\section{Considerações finais}

O conceito freireano de práxis autêntica corresponde à ideia de prática pedagógica transformadora, alicerce para a educação libertadora. Para que se chegue a esta dimensão, é necessário ao docente de Ciências da Natureza compor uma prática que abranja uma profunda relação entre seu ato pedagógico e sua consciência em torno desta, sua práxis.

A pesquisa nos mostra a dialética inerente ao movimento praxiológico, que se faz vivo, intenso, intencional, onde o combustível da práxis se revela pelos níveis de consciência praxiológica do docente, em torno de sua própria prática cotidiana.

Na intencionalidade da consciência, o homem se faz um ser de práxis. No gradual avanço de seu nível de consciência, o docente se faz praxiológico transformador. Não há práxis autêntica sem consciência crítica, assim como não há práxis autêntica sem que se considerem os sujeitos da ação, seus contextos socioculturais e econômicos, em seus processos educativos.

Se a conscientização é o que move a práxis rumo à práxis pedagógica autêntica e à Educação Libertadora (Freire, 1987), são os estruturantes da práxis que garantem sua dialética, pela reflexão e ação docente frente a si e aos educandos. Dessa maneira, é preciso pesquisas como esta, que remetem ao avanço do entendimento da estrutura e da dinâmica da práxis inclusa nas dimensões praxiológicas, contribuindo para a continuidade da pesquisa em Educação em Ciências.

Através das análises dos dados obtidos, os conhecimentos gerados pela elaboração 
e categorização dos estruturantes praxiológicos traçaram um canal de comunicação entre outras pesquisas relacionadas ao desenvolvimento da práxis pedagógica autêntica, como Stuani (2016), Lima (2019) e Silva (2004). Os estruturantes praxiológicos sujeitos, contextos e processos demonstraram ser o elo de ligação com categorias freireanas referenciadas neste estudo e também com outras de caráter freireano: quefazer, práxis autêntica, ser mais, investigação temática. Sobremaneira, os resultados obtidos pela ótica da práxis pedagógica autêntica, colaboram tanto de maneira ímpar nesta pesquisa para a elaboração de um construto teórico para dimensionar a práxis docente, como de maneira conjunta à outras, buscando avanços em relação às discussões realizadas no âmbito pedagógico, como também na área de pesquisa em educação em Ciências, com foco na perspectiva freireana, seja na formação de professores, práxis organizativa curricular ou construção de marcos teóricos que fundamentam o trabalho docente. Há que se considerar que, ao se almejar a transformação social através do desenvolvimento de uma práxis autêntica em sala de aula, pelo docente, se torna primordial que este entenda, conheça e transforme sua práxis pedagógica via processos de reflexão-ação em torno de sua prática docente, tendo em vista desencadear processos educativos que objetivem a aprendizagem crítica dos alunos e futuras pesquisas daí decorrentes.

Há de se convir que o processo praxiológico de uma prática pedagógica autêntica exige a reconstrução de conceitos, olhares, visões de mundo do educador sobre seu próprio caminhar docente e sobre seu papel social na formação de sujeitos históricos. Alcançar a práxis pedagógica autêntica implica em um processo contínuo. Para chegar a ela, o docente precisa refletir e agir, desconstruindo seu molde neutro e empírico e, principalmente, a objetivação do aluno, passando a considerá-lo sujeito ativo, interferente e atuante no âmbito da prática pedagógica. Visto o aluno dessa maneira, como sujeito da ação junto ao docente, seu contexto se faz presente. Não há movimento dialético voltado à conscientização e à práxis pedagógica autêntica que não esteja sincronizado às situações dos contextos sociais, que culminam em processos pedagógicos praxiológicos emancipadores.

Salientamos a necessidade da constância do movimento dialético entre teoria e prática docente de Ciências da Natureza alinhada à práxis pedagógica autêntica, que exige o quefazer docente como sujeito ativo do processo educacional rumo à superação de concepções de ensino de ciências voltadas ao desenvolvimento de habilidades e competências, voltadas à uma perspectiva educacional tecnicista e mercadológica, conforme prevista em documentos educacionais oficiais.

Para que o docente de Ciências da Natureza possa caminhar na direção da Educação Libertadora e da práxis pedagógica autêntica freireana, bem como entenderse como sujeito em processo de construção de consciência praxiológica em conjunto a outros sujeitos, sociedades, culturas e contextos, construindo lado a lado seus processos educativos e científicos, faz-se necessária cada vez mais a elaboração e o desenvolvimento de processos formativos permanentes, de práticas curriculares e didático-pedagógicas, 
balizadas pelos fundamentos da Abordagem Temática Freireana (Delizoicov et al., 2002; Silva, 2004) via temas geradores.

\section{Agradecimentos}

O presente relato de pesquisa resulta de aprofundamentos e articulações teóricas oriundos da dissertação de mestrado da primeira autora (Madureira, 2019), orientado pela segunda autora. Cabe-nos sobretudo agradecer as contribuições dos membros da banca de qualificação e defesa da dissertação: Prof. Dr. Fernando de Faria Franco (UFSCar) por apontar possíveis aprofundamentos em torno de aspectos históricos e filosóficos da Ciência; Prof. Dr. Antônio Fernando Gouvêa da Silva por ressaltar o uso da obra de Lefebvre e por contribuir na coorientação da dissertação, no período pósqualificação; Profa. Dra. Simoni Tormöhlen Gehlen por sugerir aprofundamentos da pesquisa em torno dos níveis de consciência em Freire. Acatamos tais sugestões, de modo que o resultado consiste no presente artigo.

\section{Referências}

Bachelard, G. (1968). O novo espírito científico. Tempo Brasileiro.

Caldeira, A. M. S., \& Zaidan, S. (n.d). Prática pedagógica. In D. A. Oliveira, A. C. Duarte, \& L. M. F. Vieira (Org.). Dicionário: trabalho, profissão e condição docente. http://www. gestrado.net.br/?pg=dicionario-verbetes\&id=328

Chauí, M. (1996). Convite à Filosofia. Ática.

Cunha, N. (1988). Brinquedo, desafio e descoberta. FAE.

Delizoicov, D., Angotti, J. A. P., \& Pernambuco, M. M. C. de A. (2002). Ensino de Ciências: Fundamentos e Métodos. Cortez.

Franco, M. A. R. S., \& Gilberto, I. J. L. (2010). O observatório da prática docente como espaço de compreensão e transformação das práticas. Práxis Educacional, 6(9), 125-145.

Freire, P. (1967). A educação como prática da liberdade. Paz e Terra.

Freire, P. (1979). Conscientização: Teoria e prática da libertação: Uma introdução ao pensamento de Paulo Freire. [Tradução de Kátia de Mello e Silva; revisão técnica de Benedito Eliseu Leite Cintra]. Cortez \& Moraes.

Freire, P. (1987). Pedagogia do Oprimido. Paz e Terra.

Freire, P. (1996). Pedagogia da Autonomia: Saberes necessários à prática educativa. Paz e Terra.

Goldmann, L. (1974). A Criação Cultural na Sociedade Moderna. Difusão Europeia do Livro. 
Gomes, R. R., \& Friedrich, M. (16 de agosto, 2001). A Contribuição dos jogos didáticos na aprendizagem de conteúdos de Ciências e Biologia. I Encontro Regional de Ensino de Biologia, Rio de Janeiro, Brasil.

Lefebvre, H. (1975). Lógica formal/lógica dialética. Civilização Brasileira.

Lima, J. A. (2019). A abordagem temática freireana na elaboração de um projeto políticopedagógico configurado como práxis criadora [Dissertação de Mestrado não publicada]. Universidade Estadual de Santa Cruz, Ilhéus, Bahia.

Madureira, C. A. (2019). O ato de ensinar ciências: Limites e possibilidades da prática pedagógica em sua relação com as diferentes concepções de práxis [Dissertação de Mestrado não publicada]. Universidade Federal de São Carlos, Sorocaba, São Paulo.

Mallmann, E. M. (2008). Mediação pedagógica em educação a distância: Cartografia da performance docente no processo de elaboração de materiais didáticos. [Tese de doutorado não publicada]. Universidade Federal de Santa Catarina, Florianópolis, Santa Catarina.

Marx, K. (2005). Teses sobre Feuerbach. In K. Marx, \& F. Engels (Org.) A Ideologia Alemã (pp. 117-120). [Tradução de Frank Müller]. Martin Claret.

Mehes, R., \& Maistro, V. I. de A. (7-9 de novembro, 2011). A Contribuição dos Conceitos Transmitidos pelas Charges e Quadrinhos para a Aprendizagem da Biologia. In X Congresso Nacional de Educação - EDUCERE/I Seminário Internacional de Representações Sociais, Subjetividade e Educação - SIRSSE. Curitiba. https://educere. bruc.com.br/arquivo/pdf2011/4307_2314.pdf

Moraes, M. (2004). A Ciência como Rede de Atores: Ressonâncias filosóficas. História, Ciências, Saúde, 11(2), 321-333.

Moraes, R., \& Galiazzi, M. do C. (2011). Análise textual discursiva. Unijuí.

Oliveira, P. C., \& Carvalho, P. (2007). Consciência e conscientização. Paidéia, 17(37), 219-230.

Praia, J., Gil-Pérez, D., \& Vilches, A. (2007). O papel da natureza da ciência na educação para a cidadania. Ciência \& Educação, 13(2), 141-156.

Silva, A. F. G. (2004). Das Falas Significativas às Práticas Contextualizadas: A construção do currículo na perspectiva crítica e popular [Tese de Doutorado não publicada]. Pontifícia Universidade Católica de São Paulo, São Paulo, São Paulo.

Stuani, G. M. (2016). Abordagem Temática Freireana: Uma concepção de formação permanente dos professores de ciências. [Tese de Doutorado não publicada]. Universidade Federal de Santa Catarina, Florianópolis, Santa Catarina.

Torres, R. M. (2000). Reformadores y docentes: el cambio educativo atrapado entre dos logicas. In L. Cárdenas, A. Rodriguez Céspedes, R. M. Torres (Org.) El maestro, protagonista del cambio educativo. Magisterio. 
Trivinos, A. W. S. (1987). Introdução à pesquisa em ciências sociais. Atlas.

Vázquez, A. S. (1977). Filosofia da práxis. [Tradução de Luiz F. Cardoso]. Paz e Terra.

Zuin, A. A., Pucci, B., \& Ramos-de-Oliveira, N. Adorno: Opoder educativo do pensamento crítico. Vozes.

${ }^{-1}$ Cristiane Aparecida Madureira

Secretaria Estadual de Educação de São Paulo Universidade Federal de São Carlos, campus Sorocaba Sorocaba, São Paulo, Brasil

Juliana Rezende Torres

Universidade Federal de São Carlos, campus Sorocaba

Sorocaba, São Paulo, Brasil

Editora Responsável

Stefannie Ibraim

Manifestação de Atenção às Boas Práticas Científicas e de Isenção de Interesse

Os autores declaram ter cuidado de aspectos éticos ao longo do desenvolvimento da pesquisa e não ter qualquer interesse concorrente ou relações pessoais que possam ter influenciado o trabalho relatado no texto. 